Article

\title{
The Flexible Governance of Water in Cairo's Informal Areas
}

\section{Deena Khalil}

The Bartlett Development Planning Unit, University College London (UCL), 34 Tavistock Square, Bloomsbury, London WC1H 9EZ, UK; deenakhalil@gmail.com; Tel.: +44-20-7679-1111

Received: 14 January 2019; Accepted: 25 July 2019; Published: 9 August 2019

check for updates

\begin{abstract}
This article explores the relationship between informality and water infrastructure in informal areas in Egypt. I apply three concepts drawn from the wider literatures on state power and governance: Topological power, flexible governing, and the "statization" of urban space. I find that infrastructure has functioned as one of the main instruments through which the state is produced or "effected" in the daily lives of residents. Due to this, examining the governance of water infrastructure in informal areas exposes the Egyptian state's "flexibility" and the uneven nature of its power. I argue that this flexibility is a result of the ad hoc nature of power in governance and the uneven quality of the state's authority and reach. This flexibility creates a waterscape constituted by overlapping infrastructures, practices, and actors, making traditional binaries such as public-private and formal-informal meaningless. However, I find that in Egypt's post-Arab-Spring era, the state has been seeking ways to effect its presence more strongly within informal areas, and one of the ways in which it has been doing so is by incorporating "informal" users into the "formal" public water supply and allowing/forcing them to pay for water. I argue that this accommodation of informality is a way to increase the statization of informal areas, while also charging them for water usage. In this way, I find that the state's flexibility allows it to benefit from informality without having to actually "formalise" the neighbourhoods themselves or address the underlying causes of why they are labelled as informal.
\end{abstract}

Keywords: water; infrastructure; informality; Cairo; Egypt; power; governance

\section{Introduction}

"We (the GCWWC) are in charge of everything related to drinking water in Cairo. Nobody can get water without going through us first. As for those in the ashwa'eyat who steal water, they have only two options: either payment or incarceration". (Interview, Greater Cairo Water and Wastewater Company-GCWWC official, 2014)

"A few years ago some of us tried approaching the water company but they would just say insha'allah (English: God willing) and not do anything. So we figured out other ways to get water. It was only after the Caritas organisation got involved that the water company actually began connecting us". (Interview, Haggana male resident, 2014)

The above two quotations describe two very different perspectives on water provision in Cairo, Egypt. The first is from a department head within the Greater Cairo Water and Wastewater Company (GCWWC), and the second is from a resident of Ezbet El-Haggana, an area in Cairo designated by the state as "unplanned". The term "unplanned" is used in Egypt's legal code to refer to neighbourhoods that were not planned by the state. A sub-category of unplanned areas is "unsafe areas", which refers to small percentage of unplanned areas that pose health or safety risks to their residents. When the 
water company official made these comments to me, he also explained that although the GCWWC is a company, it is still a state institution and thus has the authority and means to retrieve the money owed to it by the "thieves in the ashwa'eyat" ("ashwa'eyat" is the colloquial term used in Egypt to refer to informal areas). The second quotation illustrates the reality of water provision on the ground: That although the GCWWC is the main provider of water, it is only after residents mobilised local organisations that the water company took action. The quotations contrast the image of state institutions that believe (or wish to portray) that they are in control of urban planning and governance, against the reality of the day-to-day governing of urban affairs, which is much more ad hoc and uneven.

In this article, I inquire about what the Egyptian state has achieved in terms of governing water infrastructure in informal areas. Many analyses of water provision in Egypt take a more "top-down" perspective, focusing on the different aspects of water governance. Contrarily, I adopt a perspective that focuses instead on the "bottom-up" assemblage of services as a fragmented, almost accidental process. I therefore focus less on governance through policies, plans, and legal decrees and more on the daily reality of informal areas and how their residents experience access to water on a regular basis. I adopt here a broad understanding of governance as the different ways in which government actors-whether individuals or institutions-try to intervene in urban affairs with the purported aim of changing or improving conditions. This definition of governance adopts a more state-centric perspective than some of the more mainstream definitions (e.g., Bakker, 2003 [1]) that depict a more pluralistic process. Bakker (2003) defines governance as "the process by which stakeholders articulate their interests, their input is absorbed, decisions are taken and implemented, and decision-makers are held accountable". Contrarily, my view of governance as a process carried out almost exclusively by the state is in line with the experiences of many countries under heavily centralised and/or authoritarian regimes. I focus specifically on access to drinking water in Ezbet El-Haggana (hereafter referred to simply as Haggana) — an unplanned neighbourhood in the eastern part of Cairo, Egypt—while situating the analysis within the governance of water in informal areas more broadly.

To conduct the analysis in this research, I employ two main conceptual tools. Firstly, I reflect on the claim by Desai (2012) [2] that the Indian state governs its informal areas "flexibly" by employing practices that contradict official discourse. I also explore the claim by Mahadevia (2011) [3] that such contradictions are part of a deliberate plan by the state to confuse citizens. I examine the application of these ideas to the Egyptian case by looking into the "flexibility" of how water is governed in Haggana. Secondly, I draw on wider discussions of power in governance by Collier (2009) [4], Griffin (2012) [5], and Allen (2016) [6], particularly their conceptualisation of power in governance as topological, contingent, and necessarily uneven. I relate this notion to infrastructure by arguing that we need to distinguish between our analyses of infrastructure as a subject or instrument of power, and of infrastructure as an object of power through governance interventions or development efforts. By doing this we remove any conceptual contradiction between depicting infrastructure as an effective instrument of state power and an object of government interventions that can exhibit the truly contingent nature of power in governance, as I do in this article. In other words, infrastructure is not only a materialisation of state governance policies and practices, but it also a manifestation of the state itself and its power.

In doing this, I situate this article within ongoing scholarly debates on informality within the urban waterscape, and its relationship to access and governance. In this regard, there are two main bodies of literature that I draw from. The first is scholarship on the relationship between informality and infrastructure in urban areas, and how this relationship affects peoples' experience with accessing resources. The second is the body of research by political ecologists focused on the relationship between nature, infrastructure, and the state.

A number of analyses of infrastructure have examined how people experience infrastructure within informal areas, and have offered invaluable insights into the workings of cities, resources, and politics in everyday life. The objects of these studies have ranged from specific forms of infrastructure such as water, sanitation, and electricity networks (e.g., Ranganathan, 2014 [7]; Desai, McFarlane and 
Graham, 2015 [8]; Silver, 2015 [9]), to specific components of those infrastructures such as meters (e.g., Loftus, 2006 [10]; von Schnitzler, 2016 [11]; Baptista, 2016 [12]). For example, Graham, Desai, and McFarlane (2013) [13] demonstrate how certain discourses around city water shortages and water theft have been mobilised to demonise informal areas as spaces that must be reproduced in order to protect Mumbai's image as a global city. Bjorkman (2014) [14] shows how water infrastructure in a Mumbai slum has become imbricated with residents' ability to navigate a constantly changing waterscape. The local waterscapes described by the author differ so much from neighbourhood to neighbourhood, that it is not sufficient to have "knowledge of water flows in a particular moment" [14], but it is rather necessary to have social networks within the neighbourhood that guarantee the constant flow of updated information regarding water flows. These social networks enable residents to make strategic choices regarding what actions to take, in light of risks associated with water cut-offs, water pressure changes, and police raids to remove illegal connections. Anand (2011) [15], looking at water in informal areas in Mumbai, argues that water pressure functions as a political tool shaping inequitable access to water, by allowing high water pressure in elite areas and limiting water pressure in poorer areas. Truelove (2016) [16] examines a state-led initiative to provide water to a slum settlement in Delhi and finds that a variety of political assemblages between state and non-state actors are involved in the everyday regulation and governance of water. McFarlane (2008) [17] finds in analysing Mumbai that a state-led sanitation project was partially aimed at disrupting existing clientelistic networks around sanitation that reflected voting patterns along religious and ethnic lines.

In reference to the contested nature of the state in water governance, Ahlers et al. (2014) [18] highlight the notion of "negotiated statehood" to understand the role of the state, particularly with regards to informality in the urban waterscape. The notion of the negotiated state provides a frame for understanding the multifarious nature of the urban waterscape and its overlapping practices that cannot be categorised as formal or informal. It calls for understanding that state bodies are not the only actors that hold the power to make "binding decisions on members of society" [18], but rather that shaping the urban waterscape is a contested process that often results in "hybrid arrangements" [18]. In viewing the state this way, it becomes clear that the state has different "capacities and limitations at different operating scales" [18]. In light of this discussion, Ahlers et al. (2014) [18] call on scholars to widen the scope of debates around informality and infrastructure, in order to benefit from other disciplines and bodies of literature. For example, drawing on ideas from fields such as political geography and state theory could provide innovative insights into how we can understand the way the state operates in informal areas.

The employment of insights from other disciplines in analyses of access to resources is something many political ecologists have engaged with, especially in recent years. Debates around what questions of nature can tell us about the state and power have provided valuable insights into understanding the issues around access to water raised in this article. For example, Meehan and Molden (2015) [19] argue against anthropocentric conceptions of the state, arguing instead that "stateness" is created through the mobilisation of power and the "spatial arrangements of humans and non-humans" (p. 443). Furthermore, one of the main roles of modern states is to make nature legible (per Scott, 1998 [20]) so that it can be incorporated into the capitalist system. In a similar vein, Loftus (2018) [21], drawing on Harris (2012) [22] and Meehan (2014) [23], explains that such an understanding of the state enables us to de-fetishise it and understand it more as a relation that is produced through practice. He therefore argues that water and its infrastructure serve to produce and consolidate the effect of the state, and may either reify or disrupt state-society boundaries. Harris (2017) [24], drawing on Meehan (2013) [25] and Grundy-Warr et al. (2015) [26], claims that the material conditions of natural resources (such as their topography), as well as their associated infrastructure, are "crucial to map and speak to the uneven geography of state power". Such an understanding enables us to see the contested state of infrastructure in informal areas as a reflection of the contested nature of the state itself-or, in other words, the state's incompleteness (Kelly-Richards and Banister, 2017 [27]). Similarly, Rodina and Harris (2017) [28] show that studying infrastructure in marginalised neighbourhoods can shed 
light on how the effect of the state is experienced in uneven ways both spatially and socially. They examine access to water in a marginalised neighbourhood on the outskirts of Cape Town, and find that the process of formalising housing and access to water has been accompanied with a discourse that promotes payment for water as part of the "expectations associated with individuated responsible citizenship" (p. 346). To sum up, the above contributions, and this body of literature in general, shows the importance of understanding the state as an effect that is produced through concrete things such as infrastructure and the way in which infrastructure manipulates spaces and lives. Through this process, the state comes into being, but it always incomplete and contested, and its power is always uneven. In other words, infrastructure acts as a reflection of differentiated and uneven state's relations within a given population/space.

More broadly, this article speaks to the importance of a holistic understanding of water access when addressing issues of water resources. For example, given Egypt's status as a water-scarce country, many studies focus on debates around sharing the Nile waters between Egypt and other Nile countries, and Egypt's national share of freshwater. This is, of course, an important and necessary debate. However it is also crucial to understand that access to potable water in many countries tends to be an issue of inequitable distribution of water within different spaces of a single country or city. Nevertheless, debates around national shares of freshwater are often mobilised to justify spatially unequal distribution of potable water, and this has been a common trope in the discourse used by Egyptian government authorities to the media. These issues, while pertinent, are unfortunately outside the scope of this study, but important to keep in mind nonetheless.

Ultimately, my intention is not for this research to advocate for a specific policy such as the formalisation of informal infrastructure or the adoption of different payment schemes for informal users. Rather, my hope is that this research can advocate for the importance of producing policies based on politics from the ground-up-policies that take into consideration local histories and the multiplicity of forces, actors, and relations that shape the urban landscape.

\section{Methods}

The research presented here is based on qualitative fieldwork I conducted in Ezbet El-Haggana, as well as interviews I conducted with government officials, in addition to secondary data analysis. The field research began with pilot interviews in late 2013, and then officially began in early 2014 and extended until late 2015, with some follow-up visits in 2016. The fieldwork in Haggana was based on merging oral history techniques (focused on the history of water access in the area) within unstructured in-depth interviews.

I applied the oral history technique using an "infrastructure biography" method. I based this infrastructure biography method on the "house biography" method developed by Blunt (2008) [29] and used by Ascensao (2015) [30]. The method utilises ethnographic methods to collect historical and contemporary data. This approach is used to "tell stories of particular dwellings and their inhabitants over time and reveal the ways in which a house itself, and domestic life within it, are intimately bound up with wider social, economic and political processes" (Blunt, 2008, p. 551) [29]. This method is implemented by visiting the house of the interviewee and asking the resident to tell the life story or oral history of their home (Ascensao, 2015) [30]. Applying this to infrastructure, I asked residents to show me their water meters and taps and tell me the life story of how these came to be. The end result is what can be considered a type of micro-history (Ascensao, 2015) [30] of each interviewee's at-home water infrastructure. The combined micro-histories of household infrastructures collectively enabled me to construct an infrastructural history of an informal area. This, in turn, contributes to the overarching goal of understanding how the urban waterscape is constituted, governed, and contested in informal areas.

In order to reach residents, I relied on a combination of purposive and snowball sampling. The purposive sampling was done through a local non-governmental organisation (NGO) that was assisting me with my research (which has requested to remain anonymous), and I chose to target homeowners 
since they are the ones responsible for installing water infrastructure. The snowball sampling was achieved through my personal relationships with certain residents who then introduced me to their neighbours and friends. Overall, I conducted 44 interviews with Haggana residents (14 male, 30 female), four interviews with staff members of various non-governmental organisations (NGOs) and community based organisations (CBOs) operating in Haggana, nine interviews with government officials, and six interviews with academics and urban experts.

In addition to the interviews, I also gathered information from residents through a community workshop I co-organised in 2014. The workshop consisted of 17 residents (eight male and seven female) from different backgrounds (including five college students, three elderly residents, three teachers, one researcher, four NGO staff, and one headmaster of a local school). It began with an open discussion on the purpose of the workshop and the issues that would be discussed. The participants were then divided into four groups, and each group engaged in a mapping exercise to produce a map of Haggana from their perspective, highlighting the most important sites and services within the area. During this group activity I posed questions to the different participants about the state of water infrastructure in the neighbourhood as a whole, and in their homes specifically. The workshop then concluded with an open discussion with the whole group, which revolved around a number of topics including infrastructure and water. I organised this workshop as part of TADAMUN: The Cairo Urban Solidarity Initiative, with which I was working at the time, and integrated questions relevant to my research. This was done with the assistance of the aforementioned local NGO who assisted in reaching out to residents and who also kindly offered us the use of their premises. The workshop was recorded by the TADAMUN initiative and partially documented on the TADAMUN website (The documentation of the workshop can be accessed at http://www.tadamun.co/?post_type=voice\&p=5229\&amp;lang=en\&lang=en\#.XNftX5Mzbq0), while I documented in writing the responses to the additional questions I posed.

\section{A Note on Informality}

Prior to providing contextual background about the neighbourhood discussed in the remainder of this article, it is important to provide a brief overview of the ongoing debate around how to conceptualise informality, as well as the nature of how the Egyptian state deals with informal areas.

Though much of the policy-oriented literature speaks of the formal and the informal as two easily distinguishable sectors, in reality informality is much less tangible, and what seem to be formal and informal often overlap. Due to the complex and multifarious nature of the informal, theoretical discussions of informality have burgeoned over the past several decades, and many voices have called for a dismissal of the formal-informal binary in favour of a formal-informal continuum. For example, Beneria and Roldan (1987) [31] stress that dualistic divisions between the formal and in the formal lead to "conceptual problems and shortcomings", claiming that in reality the two overlap in various ways. This division, according to the authors, is an artificial one. Similarly, Portes (1983) [32] encourages the perspective that rejects dualistic understandings of a formal-informal divide and instead highlights the overlaps between different ways of acting within a single economy. Roy (2005) [33] explains that rather than being part of a binary, informality should rather be seen as an entanglement of relationships that connect various spaces together. It should thus be understood as a mode of urbanisation that is never entirely separate from formal urbanisation. McFarlane (2012) [34] expands on the above conceptualisations to understand informality as a form of urban practice. He describes the relationship between formality and informality as a "meshwork" (p. 101) of varying practices that is not a pre-existing fixed category but is rather always in formation. From this perspective, actors within the city are constantly moving between formal and informal activities. McFarlane thus views the formal-informal divide as a tool that is "deployed by states as an organisational device that allows particular domains and forms of intervention (e.g., around resource allocation, service provision, or statistical monitoring)" (p. 91).

Building on this, I conceptualise informality as primarily a discourse employed by the state to exert its power by casting certain spaces/populations as legitimate and others as illegitimate. In the 
words of Ahlers et al. (2014) [18], "formality and informality are fluid concepts that say more about the authority to legitimate certain practices than describe the condition of that particular practice" (p. 2). An important point in this understanding is that informality should not be seen as something that exists outside of the state, but rather something partially produced by state practices. The understanding of informality as a discursive practice of legitimising and delegitimising highlights the ways in which states can manipulate and mobilise the categories of informal and illegal to permit or criminalise different practices (Cheng, 2014 [35]; Misra, 2014 [36]; Kooy, 2014 [37]). For example, Cheng (2014) [35] finds that informal water vendors in Manila were incorporated into the water utility's operation in certain parts of the city, and in these areas the water vendors are accepted as part of the formal public service. In other parts of the city where the vendors have not been asked to partner with the utility, they are still considered informal. Similarly, Kooy (2014) [37] shows how informal practices Jakarta's urban water supply was framed as opposing the state-promoted modern infrastructural ideal. This discourse of delegitimisation was part of a major international development project that ultimately resulted in the introduction of the private sector into Jakarta's urban water supply. Such examples show how contradictory discourses around informality are often mobilised in order to serve different political agendas. Thus, informality cannot be simply defined as everything that lies beyond the state's influence (Ahlers et al., 2014) [18] but is rather produced by and intimately tied to the state's regulatory practices. Informal areas are informal not because they are poor or do not have proper tenure documents (many homes in upscale areas lack proper tenure documents but are not labelled by the state as informal). Rather, they are informal because the state designates them as such. City-dwellers engage in informal practices throughout the city and across the socioeconomic spectrum, but certain practices are labelled as informal while others are not. This does not mean that the formal-informal binary does not exist, but rather that creating this binary is one of the discursive tools employed by modern states to manipulate and control space and the populations that inhabit it.

This conceptual overview is crucial in order to understand the awkward place that informal areas occupy within Egypt's legal and governance systems. For example, in Egypt one can easily come across an apartment that has been inhabited informally (through an uncertified sale or rental agreement) within a formal building, or a building that has been built informally (without a building license) on a formally registered piece of land. Alternatively, the land may be state-owned land that residents squatted upon, and thus the entire neighbourhood is considered informal. In other words, there are various scales of informality that often overlap, making it difficult to be conceptually robust when discussing the formal-informal divide.

Furthermore, although residents of informal areas are often portrayed as people who are living illegally, Egypt's legal code does not criminalise them. On the contrary, the Universal Building Law (Law 119/2008) states that informal areas should be upgraded as needed, and that only unsafe areas should be demolished. Moreover, several decrees have been issued over the past decades mandating that utility companies connect illegal buildings to the public utility networks and/or find ways to charge them for their usage. During the 1990s many informal areas were incorporated within the local urban administration system that divides cities into municipalities (known in Egypt as hayy) and sub-districts (known in Egypt as shiaakha). The result of this is that even though a neighbourhood, such as the Ezbet El-Haggana area discussed below, may be designated by the state as informal and have no officially recognised tenure documents, it is still represented in neighbourhood-level elected bodies, and receives part of the local development budgets that are allocated to the municipalities. Thus, informal areas in Egypt are simultaneously pathologised and demonised in mainstream discourse, while also being included in public service-provision and upgrading schemes.

\section{Background}

Today around $60 \%$ of Egypt's population live in areas designated as "unplanned" by the Informal Settlement Development Facility (ISDF). Ezbet El-Haggana is an unplanned area on state-owned desert land, lying at the eastern edge of Cairo along the Cairo-Suez desert highway (see Figure 1). It is also 
known by the name "Kilo 4.5", Ezbet El-Haggana is in the eastern part of Cairo governorate, Haggana today constitutes a sub-district (shiaakha) of the East Madinat Nasr (EMN) municipality.

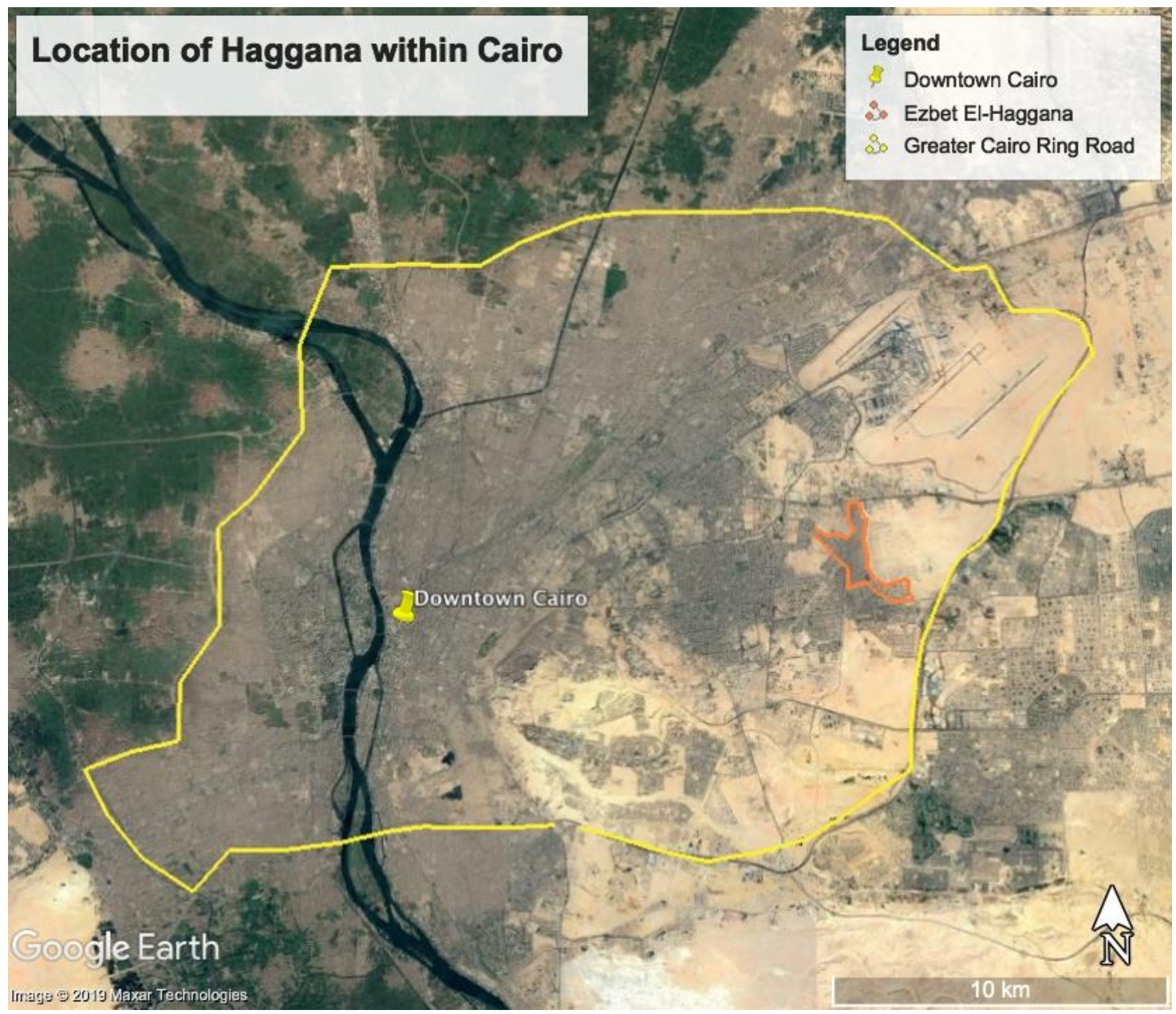

Figure 1. The borders of Cairo, encompassing the borders of East Nasr City, encompassing the borders of Ezbet El-Haggana. Source: Author.

Ezbet El-Haggana is one of the 14 informal areas that have full water network service, and the neighbourhood also has a wastewater network (Cairo Governorate, 2013) [38]. Haggana constitutes $58 \%$ of the total number of people in East Madinat Nasr (EMN) who are outside the public water network, $14 \%$ of those in EMN who rely on a tap outside their building, and $27 \%$ of those in EMN who rely on a tap inside their building but outside their housing unit (CAPMAS, 2006) [39].

Estimates of the population size of Ezbet El-Haggana vary widely, as is the case with most informal areas in Egypt. The 2017 national census estimates the neighbourhood's population to be around 39,432 (CAPMAS, 2017) [40], but many claim that this is grossly underestimated. For example, local NGO Al-Shihab Institution for Comprehensive Development estimates the population to be close to one million inhabitants. The neighbourhood developed on a piece of vacant state-owned desert land in Eastern Cairo in the 1960s. The name "Kilo 4.5" emerged because the main entrance to Haggana lies on the Cairo-Suez highway at a point that used to be $4.5 \mathrm{~km}$ from the city. The name "Ezbet El-Haggana" derived from the original function of the area as a settlement for the families of the Egyptian army's camel corps, which is the translation of the word Haggana. The camel corps soldiers were allowed to build homes for their families in the neighbourhood, and eventually, during the construction of the adjacent Madinat Nasr district during the 1960s, Haggana became attractive to construction workers that came from across Egypt to find work in Madinat Nasr. As informal Cairo boomed during the 
1970s in the wake of then-president Sadat's "open-door" policy, so did the population of Haggana, which became a haven for lower-income families coming from Upper Egyptian villages in search for better living opportunities in the nation's capital. Today, the area is a lively residential neighbourhood that hosts people from a wide range of income groups. Data on income levels are, unfortunately, not publicly available at the local level, but all residents I spoke with during the course of this research referred to certain parts of Haggana being more expensive areas that host wealthier families, especially the area near Haggana's main entrance on the Cairo-Suez highway.

Despite the existence of some upper-income families, the area as a whole fairs worse than the rest of the EMN municipality, which it is part of. For example, the Central Agency for Public Mobilisation and Statistics (CAPMAS) estimates Haggana's poverty rate at $10 \%$ while it estimates East Madinat Nasr's poverty rate to be $2.5 \%$ (CAPMAS, 2013) [41].

"I came here in 1995 and it was like a desert. It had a very bad reputation. I never left the house alone, and even with my husband I wouldn't walk outside after dark. It was almost empty, there were very few people here, the only area that was a bit lively was around the 4.5 entrance. There was no water or electricity, we had to fill jerry cans from a standpipe and carry them home, and we had to use gas lamps to light our homes. It wasn't safe at all, I was scared to walk out of my home alone, there were many thieves, they could break into your home. 4.5 was known as the place where all the thieves in Egypt lived. Today it is so much better, it is almost like a normal neighbourhood now. The area today is well-inhabited, and there are many good people living here. I can walk around and feel safe because the people around here know me. There are good buildings now, which attracted decent people. Now you find rich people and poor people and all different backgrounds in Haggana". (Interview, Haggana female resident, 2015)

Furthermore, although Haggana is almost always referred to as a single neighbourhood by the media, it is actually quite internally diverse. Residents refer to smaller communities within the area, such as the 4.5 entrance area, which hosts the wealthier families that originally settled the land, the Masakin El-Shorouk area with recently constructed residential towers hosting young families (considered one of the nicer parts of Haggana), the Daght Al-Aaly area situated under high-voltage electrical cables (arguably the poorest and most stigmatised part of Haggana), and the Tabba area, which hosts refugees from Sudan, Somalia, and Syria (Tadamun, 2015 [42]). Around 10\% of the population's residents are Christian, largely from the Upper Egyptian governorate of Al-Minya, while the majority are Muslim (Tadamun, 2015 [42]).

"My area is a good area with good people, but further up you will find the area has attracted strange people, especially under the electricity cables, that is the worst part of 4.5. And I hear that if you go up near the Tabba area you will find the place with lots of refugees, but I have never been there". (Interview 3, Haggana female resident, 2015)

Since Haggana became a "shiaakha" (the lowest urban spatial division in Egypt) in the 1990s, there has been a member of the Local Popular Council (LPC) that represents the neighbourhood (according to Egypt's local administration law, all urban municipalities have a Local Popular Council that is made up of representatives of the district, and is tasked with overseeing local development efforts). The LPC is the only form of elected local government, and the representatives of Haggana often engaged in aggressive campaigning and vote-buying. Members of parliament (MPs) have also played an important role in the area, mostly in past elections, especially during the late 1990s and early 2000s. This campaigning largely revolved around access to services, as Haggana had been marginalised from basic services due to its status as an informal area. This theme is explored in more depth in the following section. 


\section{Results}

\subsection{The Early Development of Haggana's Water Landscape}

"When I first moved here in 1978, we relied on two public standpipes for water, which were installed by the army. We would fill up our jerry cans and carry the water on our backs. But soon local strongmen (Arabic: Baltagia) took hold of these standpipes and would only allow us to take water if we would also carry water to their houses. We refused and tried to find an alternative, which we soon found when we arranged cement-carrier trucks to fill up their containers with water and transport it throughout Haggana and sell it to us. But soon the baltagia demanded that we pay for the water. I had to purchase water and the barrel lasted me only a few hours. We had to carry the water long distances, and my girls had to skip school to help me with that. When the water vendors came to Haggana in the 1980s that gave us another option to purchase a jerry can from them but it later became very expensive. Then in the 1990s there was a parliament member called Thuraya Lubna who started connecting parts of the area to the water network during election times. She would walk through the Ezba and ask people to vote for her and help us get water in our homes. She helped some of us hire a plumber and tap into the water mains nearby, even though the municipality had told us this is illegal. But in other parts of Haggana there was still no water, until El-Sallab started running for elections and he connected some others parts to the network. In 2000 the governor visited the Ezba and said water would be installed everywhere and that the connections we installed ourselves would be demolished and replaced with government pipes. We were happy about this because the network Labna helped us install was weak and the quality was not good. So we went to the municipality to see when this would happen, but they told us that 4.5 is illegal and full of thieves and will never get water. After the governor visited we kept waiting for the water company to install pipes in our street but it didn't happen, so we continued to rely on our own pipes. Finally around 2006-2007 we finally saw the water company in the Ezba digging pipes, but they didn't demolish our self-installed pipes, they just put theirs next to ours. We were also happy about this because sometimes the water would cut off from the government pipes, so we would switch to our old pipes and sometimes they would work. But they only did this in part of the Ezba, they were very slow. I got connected to the government pipes in 2007, but my mother in law didn't get connected until 2013 because the company took so many years to reach her area. She lives in a different part of the Ezba and she was not in the path of Labna or El-Sallab. But even though I had government pipes since 2007 the company came back recently to make sure everyone signs a contract with the company and gets a meter. They told us our connections were illegal, even though they are the ones that installed it! The meters were expensive so not everybody purchased one, and I did not purchase one, and when the meter-reader came to the Ezba he would just write down any number and we would have to pay it! So I finally got a meter a few months ago, but even after that sometimes the meter-reader does not come regularly and that makes me wonder from where they got the amount written on my water bill if nobody came to even read the meter". (Interview, Haggana female resident, 2014)

When Ezbet El-Haggana was first settled by the camel corps soldiers before the 1950s, water was delivered on a daily basis via trucks sent by the armed forces to fill water tanks inside homes. This constituted Haggana's first form of water infrastructure (Community workshop, Haggana residents, 2015; Interview, Haggana-based NGO manager, 2014). Through the information I gathered from the accounts of residents, I managed to construct a history of the process Haggana underwent to reach the water infrastructural landscape it has today.

Although the armed forces discontinued its delivery of water during the 1960s, they had already allowed the camel corps soldiers to build homes for their families in Haggana. Therefore, knowing that there were already several families living in the area, the armed forces built two public standpipes 
at the northern and southern edges of Haggana. These standpipes constituted Haggana's second form of water infrastructure. As Haggana's population surged through the 1970s and as its area expanded, it became a common occurrence to see physical altercations around the water standpipes due to overcrowding and long lines (Interview, Haggana-based NGO researcher, 2015; Interview, Haggana female residents, 2015). It was not long before some enterprising individuals saw the opportunity to make money, and informal water vendors appeared in the area. According to the interviewees, the choice between walking long distances carrying heavy jerry cans of water or purchasing overpriced water from a vendor was not always an easy decision. In the words of one respondent:

"The water vendor was expensive, so most days I would try to get water from the standpipe, but it was far from my house and always crowded, and my back would hurt from carrying the jerry can, so some days I would just buy from the vendor". (Interview, Haggana female resident, 2015)

Over time, the water vendors came to represent a type of water mafia. The vendors took advantage of the fact that most residents were located far from the standpipes, and regularly increased their prices. To avoid the need to rely on vendors, some of the better-off residents installed taps within their homes, which were illegally connected to the standpipes. Those who did this were mostly clustered in the 4.5 entrance area, partly because of their closer proximity to the standpipes, and partly because many of the wealthier residents resided in this area (Interview, Haggana-based NGO researcher, 2015). However, eventually, local strongmen established control over the public standpipes and were charging people a fee to use them. As one resident explained, "initially we would get water through individual efforts, and we had to pay a monthly fee to the baltagy (strongman) who had control over the valve" (Interview, Haggana female resident, 2014). This water mafia made up yet another piece of the infrastructural landscape of water in Haggana.

Some residents informed me that they approached the municipality and the Cairo water authority to ask that the pipes adjacent to Haggana be extended to its main streets. The response from both entities was that not only were they ineligible to receive services due to their illegal occupation of the land, but that the area did not even exist on the government maps (Interview, Haggana male resident, 2014; Interview, Haggana male resident, 2015). Thus, Haggana remained dependent on standpipes and water vendors.

\subsection{The Clientelisation of Informality}

As Haggana entered the 1990s, accessing basic services like water and electricity had begun to depart from the chaos of the preceding decade, characterised by repeated physical altercations between residents and individual ad hoc solutions, and instead was moving towards a more systematised approach that revolved around obtaining access through certain powerful and well-connected individuals (Interview, Haggana-based NGO researcher, 2015).

After Haggana's conversion into an administrative sub-district, residents were required to elect a representative on Nasr City's LPC. This became a vehicle for vote buying, clientelism, and corruption. Those running for office used their connections and political clout to extend the water, wastewater, and electricity networks to Haggana, despite any disapproval on the part of municipal governance. MPs running to for the Madinat Nasr seat became notorious during the 1990s and 2000s for trying to obtain votes in exchange for community services (Interview, Haggana-based NGO manager, 2014). The services they relied on the most to achieve this were water and electricity. Through their involvement in local politics and their relationships with governmental authorities and development organisations, individuals running for local office became one of the main channels through which residents obtained water infrastructure in Haggana (Community workshop, Haggana, 2014). Politicians campaigned heavily in certain parts of Haggana, and despite the fact that the Cairo governorate had issued a decree in 1991 highlighting Madinat Nasr's water shortages and decreeing that no new buildings should be built without the approval of the water utility, these politicians routinely promised (and 
delivered) connections to the water network in exchange for votes. Through this process, large portions of Haggana's residents were able to connect to the water network and receive in-home connections through the process of vote selling (Community workshop, Haggana residents, 2014).

Thuraya Labna, an MP representing Madinat Nasr in the 1987-1990 and 1995-2000 parliaments, promised residents that despite the district's water situation, she would ensure they all gained access to water, sanitation, and electricity, if they voted for her (Community workshop, Haggana, 2014). As part of her campaign, she began installing informal connections to connect some homes to the public network. Several of the residents I interviewed recalled that the first time they had in-home running water was through the connections installed by Labna's campaign.

"Thuraya Labna was a good woman, she would walk all around Haggana asking people to vote for her, and she is the one who helped me get water in my house, before that my wife would have to walk every day to the standpipe". (Interview, Haggana male resident, 2015)

"I had to purchase water and the barrel cost EGP 1.5 and lasted me one-to-two hours, and it was not even clean water; then around 15 years ago there was a parliament member called Thuraya Lubna who started connecting parts of the area to the water network during election times". (Interview, Haggana male resident, 2014)

This process was replicated by Mostafa El-Sallab, another parliamentary candidate, when he ran for parliament in the 2002 and 2005 elections (Community workshop, Haggana, 2014). As was the case with Labna, throughout both of his campaigns El-Sallab connected certain parts of Haggana to the water network. When he was campaigning in 2005, El-Sallab made a similar promise to connect all homes to electricity during the elections, and even distributed application forms to residents (Masoud and Muawwad, 2007) [43]; Community workshop, Haggana residents, 2014). As one resident stated when speaking about Mostafa El-Sallab,

"When I moved here in 1998 there wasn't any water and we purchased jerry cans for 50 piasters, and we suffered a lot in carrying the water. Now the water is good and we don't have to purchase, thanks to El-Sallab. El-Sallab did a lot of work in connecting parts of the Ezba to water, he helped us get government pipes". (Interview, Haggana female resident, 2014)

According to the residents I spoke with, the water connections provided by these politicians did not specifically target wealthier parts of Haggana or more powerful community members. Although many of the more powerful community members were well-connected to the politicians, they acted as vehicles to help the politicians reach the main constituency that could provide them with votes. Thus, local politicians and their clientelistic vote-buying politics constituted a central part of Haggana's infrastructural water landscape during the 1990s and 2000s. What is clear from the actions of every MP that has run for the Madinat Nasr seat is that informality was exploited by ruling party politicians as a way to gain votes, thus leading to a so-called "clientelisation of society" (Dorman, 2007) [44]. In the words of Dorman (2009, p. 430) [45]:

"While officials did rebuff bottom-up demands for servicing, the long-term trend has been for areas to receive local connections eventually-usually the result of a clientelistic micropolitics whereby informal communities cultivate ties to state officials and the latter use services (or at least the promise thereof) as means of cultivating support".

\subsection{Self-Help Infrastructure}

In 2000, thanks to pressure from the local politicians representing Haggana, the Cairo governorate issued a decree mandating that Haggana be physically upgraded, including officially connecting the area to the public utility networks (Decree 925/2000). Thus, in 2002 the Cairo water authority finally announced it was developing a plan to connect Haggana to the water network in five stages 
(Interview, GCWWC official, 2014). They began at the area's northern edge and proceeded inward, installing piping that was connected to the nearby water mains. At a certain point, the water authority ceased digging and moved to the area's southern edge and proceeded inward from there (Interview, Haggana-based NGO manager, 2014). Thus, large areas in the middle of Haggana fell through the cracks and did not receive water access for years. In addition, the process proceeded incredibly slowly, as many of the employees of the water authority remained resistant to the idea of connecting an informal area to water (Interview, GCWWC official, 2015).

"The governor visited the area once around 2000 and said water would be installed everywhere, but when we went to the municipality we were told that 4.5 is illegal and doesn't appear on their map". (Interview, Haggana male resident, 2014)

Even in the parts of Haggana that the water authority had reached, there were no legal or regulatory provisions at the time that allowed residents without proof of tenure to legally apply for a water connection. Thus, many continued to rely on informal water sources. Ultimately, despite the fact that public utilities were, on paper, connected to Haggana in the early 2000s, the reality is that most people continue to lack access because of the high cost of installing a home connection, the widespread poverty in the area, and the lack of proof of tenure (Interview, Haggana-based NGO manager, 2014).

The implementation by the water authority took place at such a slow pace that many of the residents who had not received connections through politicians decided to pool their resources together to construct informal connections to their streets and homes (Community workshop, Haggana residents, 2014) (see Figure 2). During the mid-2000s, several local community based organisations (CBOs), especially in Haggana's southern region, implemented projects to collect money from residents and hire plumbers to illegally tap into the nearest water mains. They hired plumbers to install 4-inch pipes down certain main streets in Haggana connecting them to the water main and to install smaller pipes connecting the side streets (Interview, Haggana-based CBO staff, 2014). Usually these projects tended to encompass the offices of the $\mathrm{CBO}$ along with the homes within the vicinity of the $\mathrm{CBO}$, thereby spreading the cost of the plumber and pipes. To ensure that government officials did not interfere with the process, the project leaders bribed security and municipal authorities (Interview, Haggana-based CBO staff, 2014). One such initiative, documented by Bremer and Bhuiyan (2014) [46] and Wahby (2013) [47], shows that the CBO members also bribed a parliamentary member who wanted to claim that the project was his own, as well as the local strongmen who had taken control of the standpipes and did not want to lose their opportunity for profit (Bremer and Bhuiyan, 2014) [46].

"Water entered my home in 2009, before that we used to purchase jerry cans. Some other people would buy a water tank, which was around 35 pounds, but only a few people could afford that. We had to carry the water long distances. My girls had to leave school to help me with that". (Interview, Haggana female resident, 2014)

The cost incurred by each family to connect to this "self-help piping" (Wahby, 2013) [47] was much lower than what residents had to pay the water company for an in-home connection. As mentioned above, many middle and southern parts of Haggana were not connected until 2012-2015, so the households in those areas continued to rely on this informal system until the water company finally arrived to connect them. The water company did not remove the informal system when it installed its own pipes, and for many years residents used the informal piping as a backup measure for when the formal system suffered from outages (Interview, Haggana-based NGO manager, 2014; Community workshop, Haggana, 2014). Several of such projects were carried out by different CBOs, such as the Al-Muiz CBO run by the locally well-known figure Samir Anwar, known for his active campaigning for candidates during parliamentary and LPC elections (Interview, Haggana-based NGO manager, 2014; Community workshop, Haggana, 2014). 


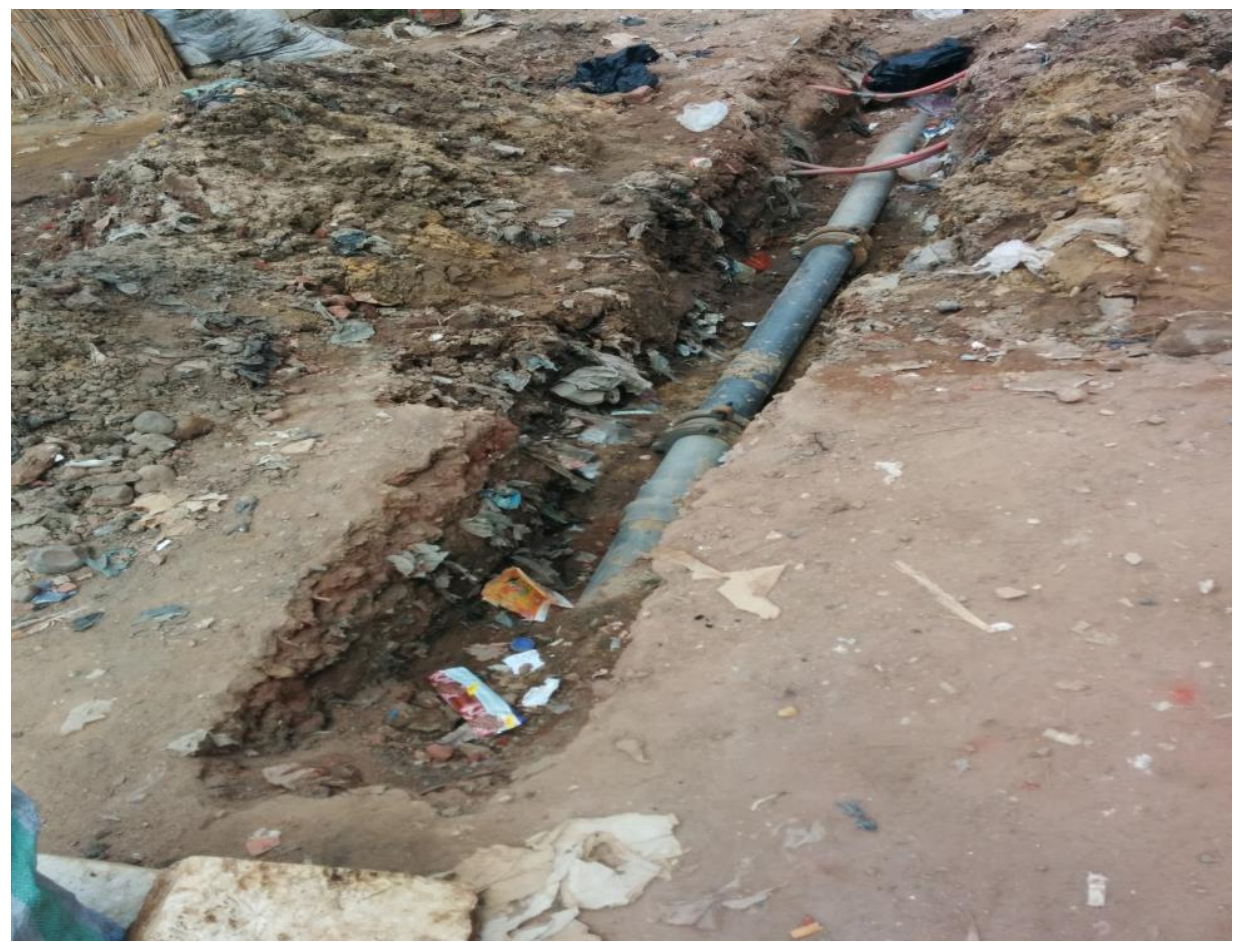

Figure 2. Self-built infrastructure. Source: Author.

The slow process of connecting Haggana to the water network continued to be stalled due to multiple conflicts between the residents and the company over the company's desire to charge high arrears for the water residents had been "stealing" (Interview, GCWWC official, 2014) over the years. The standoff was finally resolved when a local NGO received a grant and organised local water committees from Haggana's residents to advocate for their right to water through meetings with the water company and local officials. The committee was also responsible for negotiating with the local strongmen controlling the standpipes and obstructing the installation of infrastructure. The NGO also mobilised funds to cover some of the costs of the branch connections, home connections, and water meters for residents who could not afford them (Interview, Haggana-based NGO manager, 2014).

Thus, by the late 2000s the area's water infrastructural landscape could be characterised as quite variegated. Some households had a formal in-home connection to the water network, while other households were in close proximity to the sub-mains but could not afford an in-home connection and so relied on water from their neighbours. Yet other residents were on streets where no sub-mains had been installed, and thus relied on informal water vendors. Such a variegated waterscape is still characteristic of many informal areas today as explained by a Cairo governorate official discussing the situation of water in Cairo's informal areas:

"The situation in informal areas is very complicated. One of the issues we are dealing with is that when we ask the question: 'What is the service level in this area?', there is no straightforward answer. There are some areas with water in the middle, some areas with a network, some areas with an informal network, some areas with a public main at the edge, and some areas with no water at all". (Interview, Cairo governorate official, 2015)

Part of the reason for the slow pace of implementing the water authority's plan to connect Haggana has been resistance on the part of the responsible executive agencies and officials. Many officials within state institutions and municipalities often resisted connecting informal areas to utility networks because they perceived informal dwellers as thieves. For this reason, even when there was a legal mandate to connect informal areas to public networks, such decisions took years to implement due to resistance on the part of responsible executive agencies. For example, even though the Cairo governor issued 
Decree 925 in 2000 mandating that Haggana be upgraded and connected to public utility networks, the residents I spoke with dated the earliest connection to 2008 (Interview 23, Haggana male resident, 2015). In fact, an official within the GCWWC confirmed that many of the company staff continued to believe informal areas should not be connected to the water network, even though they understand this is now the new policy (Interview 42, GCWWC official, 2015).

\subsection{Post-Arab-Spring: Accommodating Informality}

When the Egyptian uprising erupted in January 2011, all installation of the public water network in Haggana halted and by the time I conducted my preliminary fieldwork in 2013 there were still areas in the south of Haggana that had not been connected to the formal network and were still dependent on informal means. Many residents shared home-based water taps, such that every two neighbours would purchase a single connection together to ease the financial burden, and some of those who obtained a home connection also installed a public standpipe in front of their home to help those less fortunate. Even among those who had been connected by the water company, many continued to rely on their old self-built informal systems during water outages (Community workshop, Haggana residents, 2014). In 2012, residents in Haggana's southern part staged a road sit-in to demand water because they had still not been connected to the public network (Wahby, 2013) [47]. When I visited Haggana again in 2014 many households in the southernmost part of Haggana continued to rely on informal connections, as the water company had not yet begun to dig pipes in that area.

Since Egypt's current president El-Sisi came to power in 2014, there has been an increased focus on what I describe as "accommodating informality". The water company has been changing its strategy by looking at ways to collect payments from the many illegal connections that exist in informal areas. To achieve this it has adopted various mechanisms to charge non-metered users who have illegally tapped into the network, such as charging arbitrary sums or introducing temporary meters that depend on prepaid scratch cards. Many GCWWC officials have repeatedly complained about the toll that illegal water connections in the ashwa'eyat have taken on the company's finances. It is within this context that we can understand why one senior official of the GCWWC stated in 2011 that the company's priority was to focus on the ashwa'eyat (Mounir, 2011) [48]. In doing this, the water company is taking a cue from the electricity company, which has been pioneering such mechanisms. After the surge in informal housing that took place in the wake of the 2011 revolution, the water and electricity companies complained of unprecedented strain being placed on the networks that were not built to serve the population sizes that were using them. They also complained of a surge in theft costing the companies millions of pounds. In the words of one official, "we have suffered a lot at the hands of the ashwa'eyat who cost the company millions because of the water they steal" (Interview 8, GCWWC official, 2014). In 2014, the head of the water company stated that there were over 800,000 illegal connections nation-wide, costing the company over EGP 4.2 million every month (Al-Gumhuriya, 2014) [49].

To address this, the water company has introduced provisions within its application procedures to regularise informal connections, labelled as "wasalat khelsa", which literally translates to stealth connections. The paperwork for regularisation is similar to that required for applying for a new connection, which is a copy of the building ownership contract, a copy of the national ID, and a copy of the building license. However, the difference is that if someone is unable to provide a building license or official contract for the housing unit, the company will accept instead an electricity bill that displays the applicant's address (Interview 42, GCWWC official, 2015). One company official informed me that the company has sent trucks to several informal areas to encourage people to apply for meters on the spot, and the company is now simplifying its procedures even further to require less paperwork, to make it easier for anyone to apply (Interview 42, GCWWC official, 2015). The residents with whom I spoke indicated that many are now in the process of obtaining formal contracts with the water company to be fully metered and charged for their consumption. An official within the Cairo Water Company told me that it was necessary for the company to do this because there were millions 
of people living in these areas stealing water and they needed to find a way to charge them (Interview 8, GCWWC official, 2014).

The electricity companies have made similar complaints about the increase in illegal connections since 2011. Thus, they have formally institutionalised the temporary prepaid meter known as 'addad cody. The company has stated that such meters are to be used by illegal buildings that cannot apply for a formal connection but should in no way be considered a form of proof of tenure (Ramadan, 2016) [50]. The water company has stated that it will follow the model of the electricity company and purchase 6.2 million temporary prepaid meters to contribute towards their cost recovery efforts, as this was a necessary measure to recover these costs until the state decides to deal with these "transgressors". The spokesperson affirmed that these meters are given a number and not any name or contract, that they are not to be considered proof of ownership or tenure, and that if the municipality decides to demolish these homes they should demolish the meters along with them (Al-Gumhuriya, 2014) [49].

By 2016, when I conducted additional fieldwork across Haggana's various neighbourhoods, I could not find anyone who did not have in-home access to water from the public network, and most of those I spoke with had water meters, meaning that their access was considered formal by the water company. However, every single one of the residents I spoke with informed me that they were embroiled in constant disputes with the company over alleged arbitrary charges and arrears. Within this context, one can understand why Haggana has been witnessing such a change in the way the Cairo Water Company interacts with them. After spending years trying to obtain water in their areas, and facing resistance and accusations of illegality from officials, Haggana's residents are today finding encouragement from the water company to apply for meters and legalise their connections (Community workshop 1, Haggana, 2014), and to pay the arrears they supposedly owe. The developments described above are taking place within a broader context of increased state attention given to informal areas with the renewed presidential interest in making a mark on the "ashwa'eyat problem" (as stated in the national constitution of 2014), especially ashwa'eyat in Cairo.

\section{Discussion}

The historical examination of Haggana's access to water highlights a highly variegated and complex water infrastructural landscape. Government statements to the media frame this complicated process in terms that make it seem as though the water authorities simply realised a need for water and filled it. It neglects to mention the multiple methods that residents had to resort to in order to obtain water, including vote selling to local politicians, taking part in self-help projects, and participating in donor-driven NGO projects. It also neglects the almost tug-of-war nature of the relationship between the residents and the authorities responsible for providing water, one that involved lawsuits, sit-ins, and resistance constantly exhibited by officials despite higher-level decrees establishing Haggana's right to water. This account of water infrastructure in Ezbet El-Haggana highlights a number of points in regards to informality and governance in the urban waterscape.

\subsection{Infrastructure and the State as Mutually Constitutive}

The analysis of water governance in Haggana highlights the mutually constitutive nature between infrastructure and state power. Griffin (2012) [5] provides an overview of the different theorisations of power in governance, ranging from the multi-level perspective of power as hierarchically nested within different tiers of the state, to the pluralistic conceptions of network governance theorists, to the more dialectical theories of relational power through structurally-determined resources and finally governmentality inspired perspectives that power is felt "immanently and everywhere" and is determined by different definitions of truth. The most common theorisation of the nature of power in governance theory has been a conception of power as locatable in the central state and extended outwards over a specific territory or downwards throughout a governmental hierarchy.

The account I presented above creates a very different picture. While it is true that the state had immense power in terms of access to resources and decision-making authority, and manipulated these 
quite well in many situations, the extent to which it was able to diffuse this power to the executive levels of government produced far more uneven outcomes. Within the context of Egypt, there is no other actor that can rival the state in terms of the authority to impose decisions and manipulate the nation's resources (land, budgets, natural resources, the military, the police, etc.). For example, the ability to issue a decree to build a new water station and then directly contract a certain authority to construct it is something only the state has the power to do. The state is also virtually the sole governing authority, as there is very limited decentralisation in governance in Egypt. This makes the state very successful at conducting "shows of force" such as infrastructural mega-projects and national events. However, this type of power does not necessarily translate into the ability to manipulate circumstances at the local level. This is similar to the argument made by Dorman (2007, p. 103) [44] who looks at the Egyptian state in informal Cairo and distinguishes between the authoritarian power of the state, and its "infrastructural capacity". He argues there is a "pronounced affinity between authoritarianism, non-interventionism, and state incompetence more generally". In a somewhat similar vein, I find that while the Egyptian state has successfully de-legitimised certain spaces within the city be labelling them as "ashwa'eyat", "informal", or "unplanned", its ability to intervene in these areas has been less effective. For decades it was not the state that provided water to residents, but rather a host of other actors including water vendors, local politicians, and NGOs/CBOs. Examining the governance of water infrastructure in informal areas exposes the "flexibility" in how the Egyptian state governs infrastructure. However, I argue that this flexibility is not deliberate, nor is it a result of the unique difficulties of managing infrastructure in informal areas, but rather a result of the ad hoc nature of power in governance and the uneven quality of the state's authority and reach.

This understanding of power relates to arguments by Griffin (2012) [5], drawing on Allen (2011) [51], that "the mere existence of a located concentration of resources or decision-making authority does not guarantee that its deployment will be successful or go un-resisted" (Griffin, 2012, p. 214) [5]. The analysis presented above shows that despite changes in Egypt's legal and policy frameworks with regards to informal areas to public infrastructure, it was over a decade before these changes materialised on the ground. This, I argued, was not due to a deliberate decision by the state to delay infrastructure in informal areas, but rather to the uneven nature of its power, despite it being virtually the sole authority in Egypt. A distinction, therefore, must be made between "latent" power [5] and actual ability to affect change. Drawing on Allen's (2016) [6] “topological” approach to power, I viewed power as spatially contingent, and a relational effect of the practices and interactions of actors, rather than a pre-existing locatable capacity. Allen (2011) [51] argues that actors "make their leverage and presence felt through certain practices of proximity and reach" (p. 290). It is the ability of central states to "reach into the politics of local areas" that can translate the type of discursive power often exhibited by states in their ability to label certain practices/spaces as informal or illegal, into the power in governance that was found to be lacking in this article. The effects of power are, therefore, "always provisional and there are no guarantees that authority at the centre will prevail" (Griffin, 2012, p. 217; citing Allen, 2011) $[5,51]$. This relates to the fact that the state is an effect produced through practice, and thus it is necessarily always spatially uneven (Painter, 2006) [52].

Thus, states must rely on other means to exert their power. Mitchell (1991) [53] describes how modern state-making relies on the internalisation of regulatory practices into daily life, with the curious result that the public imaginary of the state increasingly turns into a mythical external structure. This internalisation takes place through quotidian practices such as "the organised partitioning of space, the regular distribution of bodies, exact timing, [and] the coordination of movement" [53] (p. 82). In other words, the apparent distinction between state and society is a product of certain practices and processes of regulation. The modern nation-state functions largely through creating the appearance that it is a structure external to and encompassing of society. In the context of urban governance, the mundane practices of socio-spatial regulation, such as urban plans, zoning laws, land use regulations, allocation of basic services, administrative spatial divisions, and boundaries, or essentially anything determining what citizens can and cannot do in a given urban area, correspond to the state effect 
that Mitchell (1991) [53] describes. Indeed, as Scott (1998) [20] illustrates, states invest a great deal of time and effort into developing rules, regulations, and procedures, that together ensure that states are "imagined in some ways rather than others" (Ferguson and Gupta, 2002, p. 984) [54].

Understanding state power in such a way means that the state does not only act upon infrastructure, but also acts through it by using it as a means to intervene in and exert control over local areas. In other words, states manipulate infrastructure, but infrastructure is also constitutive of state power. Meehan (2012) [55] argues that infrastructure has the capacity of delineating and delimiting the power of the state. I build on Meehan's conception of infrastructure as a producer or delimiter of state power, but further view it as a manifestation of the state itself and its limits. More "spectacular" forms of infrastructure, such as roads, bridges, and infrastructural mega-projects in general, have been used by the state to enact and bolster its political power. While more subtle forms of infrastructure, especially water supply, have also been deployed discursively as markers of modernity and progress, the intricacies of their everyday management have enabled them to expose the state's limited power to effect real change in people's lives. This has resulted in an apparent "flexibility" in how the state governs informal areas, and by extension how water infrastructure within these areas is governed. Water infrastructure can therefore be seen as an assemblage of material infrastructure, social relations, and discourses, that come together in an almost accidental manner that reflects the uneven and "flexible" nature of state power.

\subsection{Flexibility and the Statization of the Informal Waterscape}

Such a conceptualisation of state power can help us understand the often self-contradictory practices of state authorities in governing informal areas. Desai (2012) [2] argues that the governing of informal areas in India is "flexible", a term I used earlier in this article. She highlights the disconnect between state policies and pronouncements towards the inclusion of informal dwellers as rights-bearing citizens and the actual practices of agencies that continue to exclude residents of informal areas. In her discussion, Desai (2012) [2] draws on Mahadevia's (2011) [3] description of a "paradigm of deliberate confusion" where states adopt contradictory policies in an attempt to cater to opposing political agendas by different interest groups (e.g., informal dwellers, capitalists, etc.). States may therefore adopt policies that directly harm the urban poor, while also targeting the urban poor through urban upgrading programs. The inconsistency in urban policy serves the interests of the state by "allowing policy to swing in the direction from where the pressure is coming". I highlight in this article a similar flexibility and self-contradictory practice by the state in Cairo's informal areas, especially with regards to the governance of infrastructure-though I differ in my portrayal of a state that has the power to deliberately confuse, as I argue in the previous section that the state does this despite itself, because the very nature of its power is effective in some ways but limited in others.

This flexibility renders common dichotomies such as public/private and formal/informal meaningless as the resultant waterscape is one of overlapping infrastructures, practices, and actors. The combination of plumbers, pipes, CBOs, resident cooperation, and clientelistic state-society relations, created a mix of social and physical infrastructure. Haggana's waterscape was an "archipelago" (Bakker, 2003) [56] of various combinations across the formality-informality spectrum. This is consistent with the claim by Ahlers et al. (2014) [18] that the urban waterscape often incorporates multiple overlapping service delivery mechanisms and activities that "vary according to the degree to which they are formal or informal".

However, the findings presented in Section 5.4 show that the post-2014 era has been witnessing a shift in the role of the state vis-à-vis informality in the urban waterscape. The "archipelago" nature of Haggana's pre-2014 waterscape is slowly disappearing. As detailed above, state authorities, and especially the water company, have been employing different measures to incorporate residents of informal areas into the official public water supply regime, a phenomenon I describe as accommodating informality. Such developments have led to what can be described as an increased "statization"- - a term I borrow from Painter (2006) [52]—of informal areas. This term is based on the argument that 
everyday life is permeated by the effect of the state (which he refers to using the term "stateness") through "prosaic" manifestations, including the mundane bureaucratic requirements of daily life such as filing papers, or paying for services. This conceptualisation builds on work by Mitchell (1991) [53] who depicts the state as an effect produced by real practices with material consequences-practices that include, among many other things, the "meticulous organisation of space" (p. 92). The process of the infiltration of such state-effecting practices into everyday life is what Painter (2006) [52] describes as the process of "statization". Infrastructure is often intimately tied to the degree to which different areas/spaces are statized. As argued by Harris (2012) [22], the manipulation of natural resources through infrastructure "can be understood as part and parcel of what enables the boundary between state and society to appear" (p. 26).

The findings presented above show that informal areas have been witnessing increased statization as state authorities have been exploring ways to accommodate informality in the urban waterscape. Egyptian utility companies are turning towards ways to accommodate water users that had previously been shunned as informal. However, while these residents are being allowed to formally connect to the public network, the neighbourhoods themselves remain in a state of ambiguous-if not ambivalent-legality. Residents of unplanned areas are, on the one hand, being treated as clients who must pay for services just as all other citizens do. On the other hand, they continue to be portrayed as illegal occupants who have encroached on state land. The state's flexibility in governing informal areas allows it to benefit from informality without having to deal with the many systemic issues underlying it.

\section{Conclusions}

In the above article I interrogated the role of the state in governing informality in the urban waterscape in Cairo, Egypt. Inspired by the call by Ahlers et al. (2014) [18] to apply insights from wider bodies of literature to water service delivery, I focused on the bottom-up assemblage of water infrastructure in the informal area of Ezbet El-Haggana, employing the concepts of topological power (Allen, 2011 [51]; Griffin, 2012 [5]), flexible governance (Desai, 2012 [2]), and conceptualisations of the state as an effect produced in practice (Mitchell, 1991 [53]; Harris, 2012 [22]).

Another purpose of this analysis was to illuminate the rich details of what it has entailed over the past few decades to access water in informal areas in Cairo, while also exploring how this has been changing in the last few years after the political upheaval of the Arab Spring. Examining the history of water infrastructure in the neighbourhood, I found that the process of accessing water began initially as an ad hoc process of fetching water from standpipes and purchasing from water vendors, and later developed into a system of vote selling to local politicians in exchange for the installation of infrastructure. This is a process that officials were fully participant in, yet when it came to installing infrastructure legally and formally, officials within the responsible institutions objected and obstructed the process for many years. Informality, in effect, guaranteed a certain system of benefits for local politicians and Haggana's elite. Until the late 2000s, Haggana's waterscape was characterised by an overlap of various infrastructure systems - a meshwork of formal, informal, public, and private.

One starting point I addressed in this article is the recognition that binaries such as formal-informal and public-private are quite meaningless in this context. This discourse of binaries must be analysed while remaining cognizant of the benefits it allows the Egyptian state. Ahlers et al. (2014) [18] highlight the importance of understanding how states engage in "governance through authority and legitimacy creation". Applying labels such as informal and illegal is a way for the state to manipulate spaces and lives, and create the impression of a powerful external structure that masks the reality of the state's unevenness. The manipulation of discourses and imaginaries around infrastructure renders many injustices invisible, and sometimes even denied. It allows the state to benefit from its ad hoc nature while continuing to maintain its image as a powerful external structure. To maintain this image, the Egyptian state has often relied on the manipulation of discourses, but it has also heavily relied on infrastructure. It has done this through creating "shows-of-force" such as the construction of roads 
and bridges, and the announcement of national mega-projects. In other words, infrastructure has functioned as one of the main instruments through which the state is produced or "affected" in the daily lives of residents.

However, infrastructure is both a delimiter and manifestation of the state. Due to this, examining the governance of water infrastructure in informal areas exposes the Egyptian state's "flexibility" and the uneven nature of its power. This flexibility is a result of the ad hoc nature of power in governance and the uneven quality of the state's authority and reach. In the post-Arab-Spring era, the Egyptian state has been adopting more aggressive policies to combat informality, even if this is through finding non-traditional ways of accommodating informal practices and incorporating them into the legal system. The state has been seeking ways to affect its presence more strongly within informal areas, and one of the ways in which it has been doing so is by incorporating "informal" users into the "formal" public water supply and allowing/forcing them to pay for water. This accommodation of informality is a way to increase the statization of informal areas, while also charging them for water usage. In this way, I find that the state's flexibility allows it to benefit from informality without having to actually "formalise" the neighbourhoods themselves or address the underlying causes of why they are labelled as informal.

Funding: This research was partially funded by the Ford Foundation.

Acknowledgments: This research is based on my doctoral dissertation, titled "Neoliberal Water Infrastructure, Informality, and the State in Cairo 1952-2017: A Case Study of Ezbet El-Haggana", University College London, 2018. During my field research I benefited from the support of a local NGO that has been operating in Ezbet El-Haggana since 2001, and has requested to remain anonymous. I also benefited from the support of TADAMUN: The Cairo Urban Solidarity Initiative. TADAMUN is a research initiative jointly founded and managed by Takween Integrated Community Development and American University in Washington, D.C.

Conflicts of Interest: The author declares no conflict of interest.

\section{References}

1. Bakker, K. Good Governance in Restructuring Water Supply: A Handbook; Munk Centre Program on Water Issues Ottawa, Federation of Canadian Municipalities: Ottawa, ON, Canada, 2003.

2. Desai, R. Governing the urban poor: Riverfront development, slum resettlement and the politics of inclusion in Ahmedabad. Econ. Political Wkl. 2012, 46, 49-56.

3. Mahadevia, D. Branded and renewed? Policies, politics and processes of urban development in the reform era. Econ. Political Wkl. 2011, 46, 56-64.

4. Collier, S. Topologies of power: Foucault's analysis of political government beyond 'governmentality'. Theory Culture Soc. 2009, 26, 78-108. [CrossRef]

5. Griffin, L. Where is power in governance? Why geography matters in the theory of governance. Political Stud. Rev. 2012, 10, 208-220. [CrossRef]

6. Allen, J. Topologies of Power: Beyond Territory and Networks, 1st ed.; Routledge: London, UK, 2016.

7. Ranganathan, M. Paying for pipes, claiming citizenship: Political agency and water reforms at the urban periphery. Int. J. Urban. Reg. Res. 2014, 38, 590-608. [CrossRef]

8. Desai, R.; McFarlane, C.; Graham, S. The politics of open defecation: Informality, body, and infrastructure in Mumbai. Antipode 2015, 47, 98-120. [CrossRef]

9. Silver, J. Disrupted infrastructures: An urban political ecology of interrupted electricity in Accra. Int. J. Urban. Reg. Res. 2015, 39, 984-1003. [CrossRef]

10. Loftus, A. Reification and the dictatorship of the water meter. Antipode 2006, 38, 1023-1045. [CrossRef]

11. Von Schnitzler, A. Democracy's Infrastructure: Techno-Politics and Protest after Apartheid; Princeton University Press: Princeton, NJ, USA, 2016.

12. Baptista, I. 'We Live on estimates': Everyday practices of prepaid electricity and the urban condition in Maputo, Mozambique. Int. J. Urban. Reg. Res. 2015, 39, 1004-1019. [CrossRef]

13. Graham, S.; Desai, R.; McFarlane, C. Water wars in Mumbai. Pub. Culture 2013, 25, 115-141. [CrossRef]

14. Bjorkman, L. Becoming a slum: From municipal colony to illegal settlement in liberalization-era Mumbai. Int. J. Urban. Reg. Res. 2014, 38, 36-59. [CrossRef] 
15. Anand, N. Pressure: The politechnics of water supply in Mumbai. C. Anthropol. 2011, 26, 542-564. [CrossRef]

16. Truelove, Y. Incongruent waterworlds: Situating the everyday practices and power of water in Delhi. S. Asia Multidiscip. Acad. J. 2016, 14. [CrossRef]

17. McFarlane, C. Governing the contaminated city: Infrastructure and sanitation in colonial and post-colonial Bombay. Int. J. Urban. Reg. Res. 2008, 32, 415-435. [CrossRef]

18. Ahlers, R.; Cleaver, F.; Rusca, M.; Schwartz, K. Informal space in the urban waterscape: Disaggregation and co-production of water services. Wat. Altern. 2014, 7, 1-4.

19. Meehan, K.; Molden, O.C. Political ecologies of the state. In The Wiley Blackwell Companion to Political Geography, 1st ed.; Agnew, J., Mamadouh, V., Secor, A., Sharp, J., Eds.; John Wiley \& Sons, Ltd.: Sussex, UK, 2015; pp. 438-450.

20. Scott, J.C. Seeing Like a State: How Certain Schemes to Improve the Human Condition Have Failed; Yale University Press: New Haven, CT, USA, 1998.

21. Loftus, A. Political ecology II: Whither the state? Prog. Hum. Geogr. 2018. [CrossRef]

22. Harris, L.M. State as socionatural effect: Variable and emergent geographies of the state in southeastern Turkey. Comp. Stud. S. Asia Afr. Middle East 2012, 32, 25-39. [CrossRef]

23. Meehan, K. Tool-power: Water infrastructure as wellsprings of state power. Geoforum 2014, 57, $215-224$. [CrossRef]

24. Harris, L.M. Political ecologies of the state: Recent interventions and questions going forward. Political Geogr. 2017, 58, 90-92. [CrossRef]

25. Meehan, K. Water rights and wrongs: Illegality and informal use in Mexico and the US. In The Right to Water: Politics, Governance, and Social Struggles, 1st ed.; Sultana, F., Loftus, A., Eds.; Routledge: London, UK, 2013; pp. 159-173.

26. Grundy-Warr, C.; Sithirith, M.; Li, Y.M. Volumes, fluidity and flows: Rethinking the 'nature' of political geography. Political Geogr. 2015, 45, 93-95. [CrossRef]

27. Kelly-Richards, S.H.; Banister, J.M. A state of suspended animation: Urban sanitation and water access in Nogales, Sonora. Political Geogr. 2017, 58, 104-113. [CrossRef]

28. Rodina, L.; Harris, L.M. Water services, lived citizenship, and notions of the state in marginalised urban spaces: The case of Khayelitsha, South Africa. Water Alternatives. 2016, 9, 336-355.

29. Blunt, A. The 'skyscraper settlement': Home and residence at Christodora House. Environ. Plan. A 2008, 40, 550-571. [CrossRef]

30. Ascensão, E. The slum multiple: A cyborg micro-history of an Informal settlement in Lisbon. Int. J. Urban. Reg. Res. 2015, 39, 948-964. [CrossRef]

31. Beneria, L.; Roldan, M. The Crossroads of Class and Gender: Industrial Homework, Subcontracting, and Household Dynamics in Mexico City; University of Chicago Press: Chicago, IL, USA, 1987.

32. Portes, A. The informal sector: Definition, controversy, and relation to national development. Review 1983, 7 , 151-174.

33. Roy, A. Urban informality: Toward an epistemology of planning. J. Am. Plan. Assoc. 2005, 71, 147-158. [CrossRef]

34. McFarlane, C. Rethinking informality: Politics, crisis, and the city. Plan. Theory Pract. 2012, 13, 89-108. [CrossRef]

35. Cheng, D. The persistence of informality: Small-scale water providers in Manila's post-privatisation era. Water Altern. 2014, 7, 54-71.

36. Misra, K. From formal-informal to emergent formalisation: Fluidities in the production of urban waterscapes. Water Altern. 2014, 7, 15-34.

37. Kooy, M. Developing informality: The production of Jakarta's urban waterscape. Water Altern. 2014, 7, 35-53.

38. Cairo Governorate. Strategy for the Provision of Water and Wastewater Services in Informal Areas; Cairo Governorate and GIZ, Ministry of Water and Wastewater Utilities: Cairo, Egypt, 2013.

39. CAPMAS. Population Estimates, Egypt in Figures; Central Agency for Population Mobilization and Statistics: Cairo, Egypt, 2006.

40. CAPMAS. Population Estimates, Egypt in Figures; Central Agency for Population Mobilization and Statistics: Cairo, Egypt, 2017. 
41. CAPMAS. Population Estimates, Egypt in Figures; Central Agency for Population Mobilization and Statistics: Cairo, Egypt, 2013.

42. Tadamun. Izbit Al-Haggana. TADAMUN: The Cairo Urban Solidarity Initiative. 2015. Available online: http://www.tadamun.co/?post_type=city\&p=5469\&amp;lang=en\&lang=en\#.W6YtFZN_Lq0. (accessed on 28 May 2017).

43. Masoud, A.; Muawwad, M. Ezbet El-Haggana: Million Faqir Fi Intizar Al-Rahma. Al-Masry Al-Youm. 2007. Available online: http://today.almasryalyoum.com/article2.aspx?ArticleID=47744. (accessed on 7 May 2015).

44. Dorman, W.J. The Politics of Neglect: The Egyptian State in Cairo, 1974-98. Ph.D. Thesis, SOAS University of London, London, UK, July 2007.

45. Dorman, W.J. Informal Cairo: Between Islamist insurgency and the neglectful state? Secur. Dialogue 2009, 40, 419-441. [CrossRef]

46. Bremer, J.; Bhuiyan, S.H. Community-led infrastructure development in informal areas in urban Egypt: A case study. Habitat Int. 2014, 44, 258-267. [CrossRef]

47. Wahby, N.M. Government and Community Efforts in Upgrading Infrastructure in Informal Areas-the Case of Izbit ElHaggana. M.A.; American University in Cairo: Cairo, Egypt, 2013.

48. Mounir, H. Al-Amiloon Bil Khat Al-Sakhin 125 Duyoof Ma'idat Al-Masaa. Al-Masaa. 2011. Available online: https://www.masress.com/almessa/35136 (accessed on 2 July 2016).

49. Al-Gumhuriya. Sitta Million Addad Bil Ashwa'eyat. Garidat; Al-Gumhuriya: Cairo, Egypt, 2014.

50. Ramadan, R. Al-Kahrubaa Tatalaqa 36 Alf Talab Tawseel. Al-Youm Al-Sabea. 2016. Available online: https://www.youm7.com/story/2016/6/28/\%D8\%A7\%D9\%84\%D9\%83\%D9\%87\%D8\%B1\%D8\%A8\%D8\% A7\%D8\%A1-\%D8\%AA\%D8\%AA\%D9\%84\%D9\%82\%D9\%89-36-\%D8\%A3\%D9\%84\%D9\%81-\%D8\%B7\% D9\%84\%D8\%A8-\%D8\%AA\%D9\%88\%D8\%B5\%D9\%8A\%D9\%84-\%D8\%AA\%D9\%8A\%D8\%A7\%D8\% B1-\%D9\%84\%D9\%84\%D8\%B9\%D8\%B4\%D9\%88\%D8\%A7\%D8\%A6\%D9\%8A\%D8\%A7\%D8\%AA-\%D8\% AE\%D9\%84\%D8\%A7\%D9\%84-\%D8\%A3\%D8\%B3\%D8\%A8\%D9\%88\%D8\%B9\%D9\%8A\%D9\%86/2779293 (accessed on 5 March 2017).

51. Allen, J. Topological twists: Power's shifting geographies. Dialogues Hum. Geogr. 2011, 1, 283-298. [CrossRef]

52. Painter, J. Prosaic geographies of stateness. Political Geogr. 2006, 25, 752-774. [CrossRef]

53. Mitchell, T. The limits of the state: Beyond statist approaches and their critics. Am. Political Sci. Rev. 1991, 85, 77-96. [CrossRef]

54. Ferguson, J.; Gupta, A. Spatializing states: Toward an ethnography of neoliberal governmentality. American Ethnology. 2002, 29, 981-1002. [CrossRef]

55. Meehan, K. Precious commodity: Providing water for America's cities. Environ. History. 2012, 18, $242-243$. [CrossRef]

56. Bakker, K. Archipelagos and networks: Urbanization and water privatization in the South. Geogr. J. 2003, 169, 328-341. [CrossRef]

(C) 2019 by the author. Licensee MDPI, Basel, Switzerland. This article is an open access article distributed under the terms and conditions of the Creative Commons Attribution (CC BY) license (http://creativecommons.org/licenses/by/4.0/). 